\title{
3D-CT vascular setting protocol using computer graphics for the evaluation of maxillofacial lesions
}

\section{Protocolo vascular por meio da 3D-TC utilizando a computação gráfica para avaliação de lesões maxilo-faciais}

\author{
Marcelo de Gusmão Paraiso CAVALCANTI* \\ Axel RUPRECHT** \\ Michael Walter VANNIER ${ }^{* * *}$
}

\begin{abstract}
CAVALCANTI, M. de G. P.; RUPRECHT, A.; VANNIER, M. W. 3D-CT vascular setting protocol using computer graphics for the evaluation of maxillofacial lesions. Pesqui Odontol Bras, v. 15, n. 3, p. 229-236, jul./set. 2001.

In this paper we present the aspect of a mandibular giant cell granuloma in spiral computed tomography-based three-dimensional (3D-CT) reconstructed images using computer graphics, and demonstrate the importance of the vascular protocol in permitting better diagnosis, visualization and determination of the dimensions of the lesion. We analyzed 21 patients with maxillofacial lesions of neoplastic and proliferative origins. Two oral and maxillofacial radiologists analyzed the images. The usefulness of interactive 3D images reconstructed by means of computer graphics, especially using a vascular setting protocol for qualitative and quantitative analyses for the diagnosis, determination of the extent of lesions, treatment planning and follow-up, was demonstrated. The technique is an important adjunct to the evaluation of lesions in relation to axial CT slices and 3D-CT bone images.
\end{abstract}

UNITERMS: Tomography, X-ray computed; Image processing, computer-assisted; Giant cell granuloma; Mandible.

\section{INTRODUCTION}

Computed tomography $(\mathrm{CT})$ is the most common technique used for examination of maxillofacial neoplasms because it permits the visualization of soft tissues and bone structures in the same examination. It has become the modality of choice for the evaluation of maxillofacial neoplasms $s^{5,12,9,14}$. Multiple overlapping slices can be reconstructed from a single examination permitting higher quality multiplanar (MPR) and three-dimensional reconstructed (3D) images without additional patient irradiation ${ }^{12,7,9,10,11,14}$. Recently, we presented a new methodology using a 3D vascular setting protocol for quantitative analysis of mandibular neoplasms, which was validated in cadavers ${ }^{9}$. That study showed that 3D interactive computer graphics make possible a more complete assessment of maxillofacial lesions, assisting the preoperative planning and the evaluation of postoperative outcomes ${ }^{9}$.

Aspects such as the CT technique, number of examiners, examiners' experience, and vasculari- zation of the lesion (satisfactory contrast enhancement) are important to establish acceptable reproducibility. The application of computer graphics technology from 3D spiral CT allows for direct volumetric reconstruction, fast data filing, fast and easy 3D analysis, real time imaging for guiding intervention procedures and linear and volumetric measurements ${ }^{7,9}$.

The purpose of this paper is to show the usefulness of spiral CT-based MPR and 3D reconstructed images using computer graphics protocols in the evaluation of different maxillofacial lesions, using, as an example, a giant cell granuloma of the mandible.

\section{IMAGING METHODOLOGY}

We analyzed 21 patients with different lesions. The patients were referred for spiral CT imaging (Aquilion Toshiba America-Systems Inc., Tustin, $\mathrm{CA})$ at $120 \mathrm{kVp}$ and $200 \mathrm{~mA}$, using a 512 × $512 \mathrm{ma}-$ trix, and $3 \mathrm{~mm} / 0.5 \mathrm{sec}$ of table feed to produce

*Professor, Oral Radiology, School of Dentistry, University of São Paulo, São Paulo, Brazil. Adjunct Assistant Professor; **Professor, Oral and Maxillofacial Radiology, Department of Oral Pathology, Radiology and Medicine, College of Dentistry. Professor; ***Professor - Department of Radiology, College of Medicine, University of Iowa, USA. 
CAVALCANTI, M. de G. P.; RUPRECHT, A.; VANNIER, M. W. 3D-CT vascular setting protocol using computer graphics for the evaluation of maxillofacial lesions. Pesqui Odontol Bras, v. 15, n. 3, p. 229-236, jul./set. 2001.

3-millimeter-thick slices with $1.5 \mathrm{~mm}$ of reconstruction interval. An FC 20 scanning filter and FOV of $20.3 \mathrm{~cm}$ were used, as well as intravenous contrast (150 ml of Conray 60, Mallinckrodt Medical Inc., Saint Louis, MO, USA), which permitted the visualization of soft tissue involvement and aided in the delineation of the lesion. The data sets of
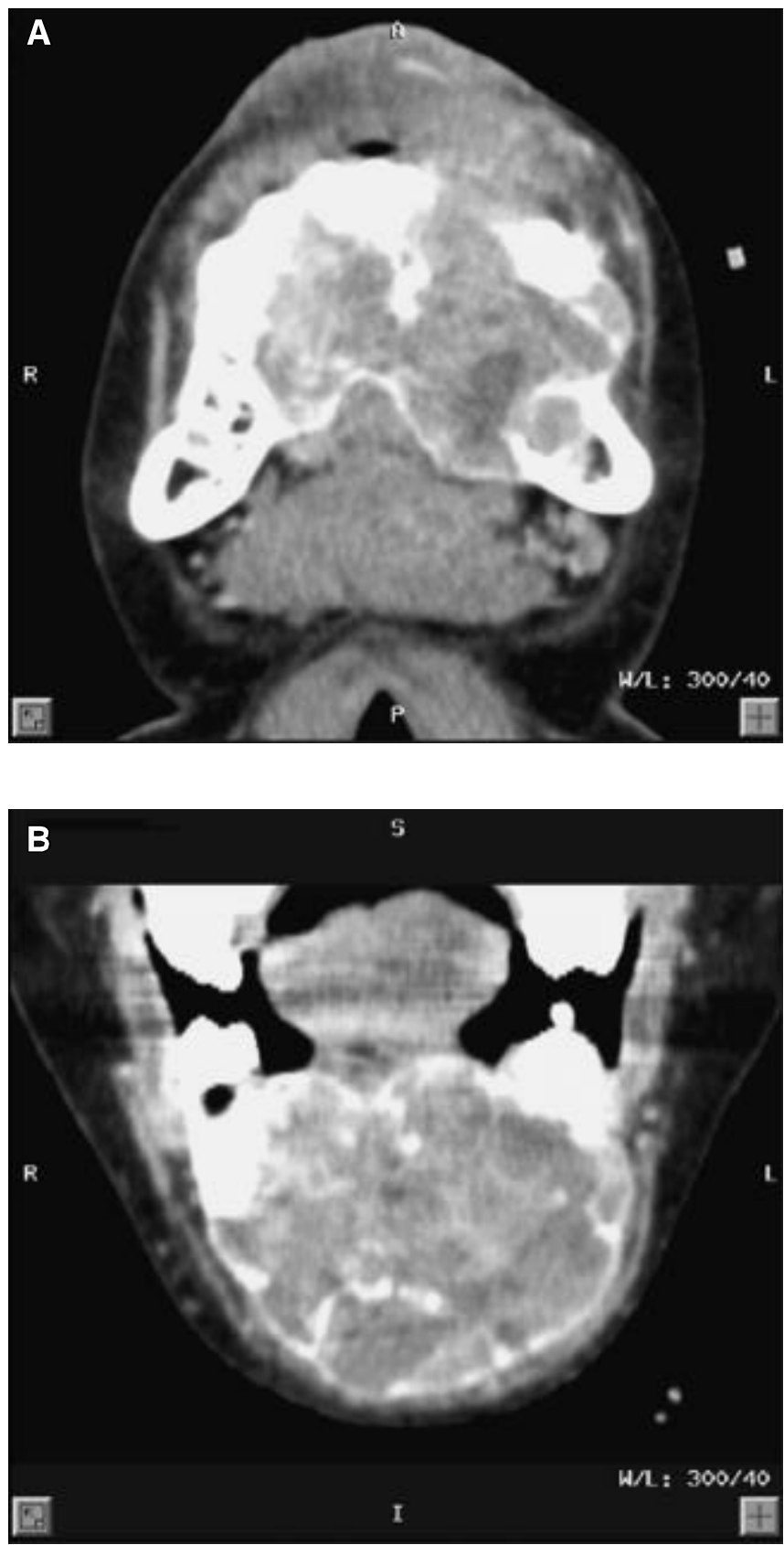

this investigation were transferred, via network, to a computer workstation (Silicon Graphics NT and DELL Precision 420 NT 4.0 hardware with Vitrea ${ }^{\mathrm{TM}}$ 2.2 software, Vital Images Inc., Minneapolis, MN, USA) to generate interactive volume-rendered 3D and MPR images.

This software allows for simultaneous display of 3D and MPR images in three planes. In this study, axial, coronal, and sagittal planes were used. This permitted the lesion and associated anatomy to be viewed from different perspectives, simultaneously (Figure 1).

The 3D images were viewed using rotation, translation, and a fly-through mode, which allowed for the visualization of the lesion in relation to relevant anatomical structures. The software tools also permitted visualization through the tumor mass, providing depiction of bone destruction in the base of the mandible, as well as osseous proliferation. The $3 \mathrm{D}-\mathrm{CT}$ examination revealed bone destruction along the anterior region extending to the body of the mandible, bilaterally, including anterior teeth and premolars, and clearly depicted the lesion within the body of the mandible (Figure 2).

The 3D volume-rendering software package offers a wide choice of settings that apply different

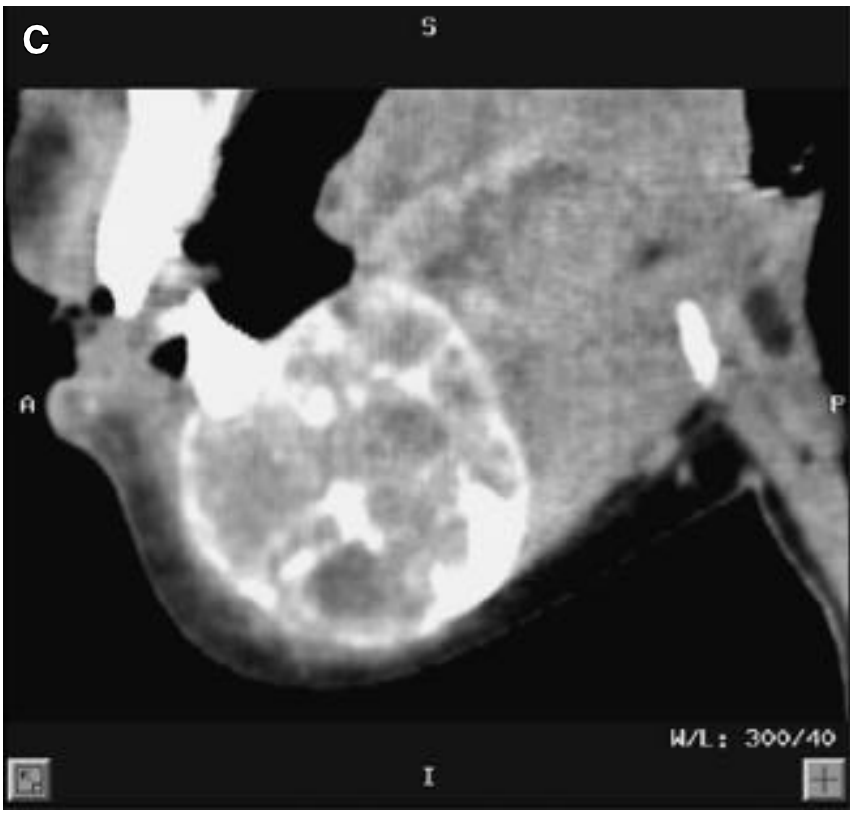

FIGURE 1 - MPR-CT images: axial (A), coronal (B) and sagittal (C) views demonstrate the degree of bucco-lingual and inferior expansion of the lesion in the body of the mandible, as well as the internal trabeculae. The CT images show a large well-demarcated multilocular mass with multiple foci of calcification, involving from the right to the left side of the mandibular body, including the region of the menton. 
CAVALCANTI, M. de G. P.; RUPRECHT, A.; VANNIER, M. W. 3D-CT vascular setting protocol using computer graphics for the evaluation of maxillofacial lesions. Pesqui Odontol Bras, v. 15, n. 3, p. 229-236, jul./set. 2001.

color tables and transparency functions to the CT data, based on CT density. Using the vascular setting, which preferentially colorized the tumor due to the increased vascularity and contrast enhancement around the periphery of the lesion, it was possible to localize the contour of the tumor, visualize all of its borders in relation to the mandible, and perform linear measurements of the neoplasm. Frontal, lateral, axial, and internal 3D vas-
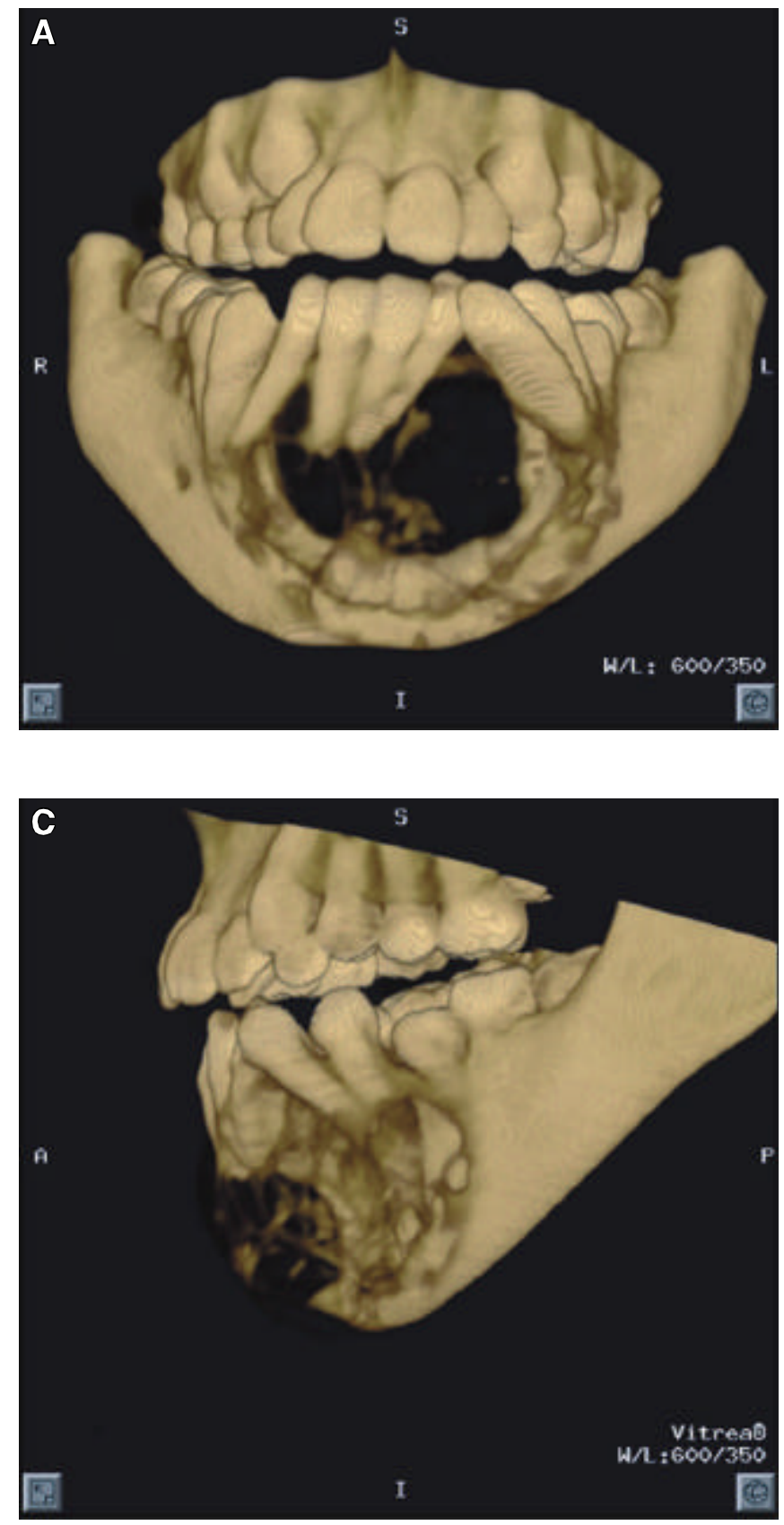

cular setting views clearly showed that the mass involved the inferior aspect of the mandible (Figure 3).

\section{RESULTS AND IMAGING INTERPRETATION}

The results reveal the number of lesions that were detected and interpreted by two radiologists,
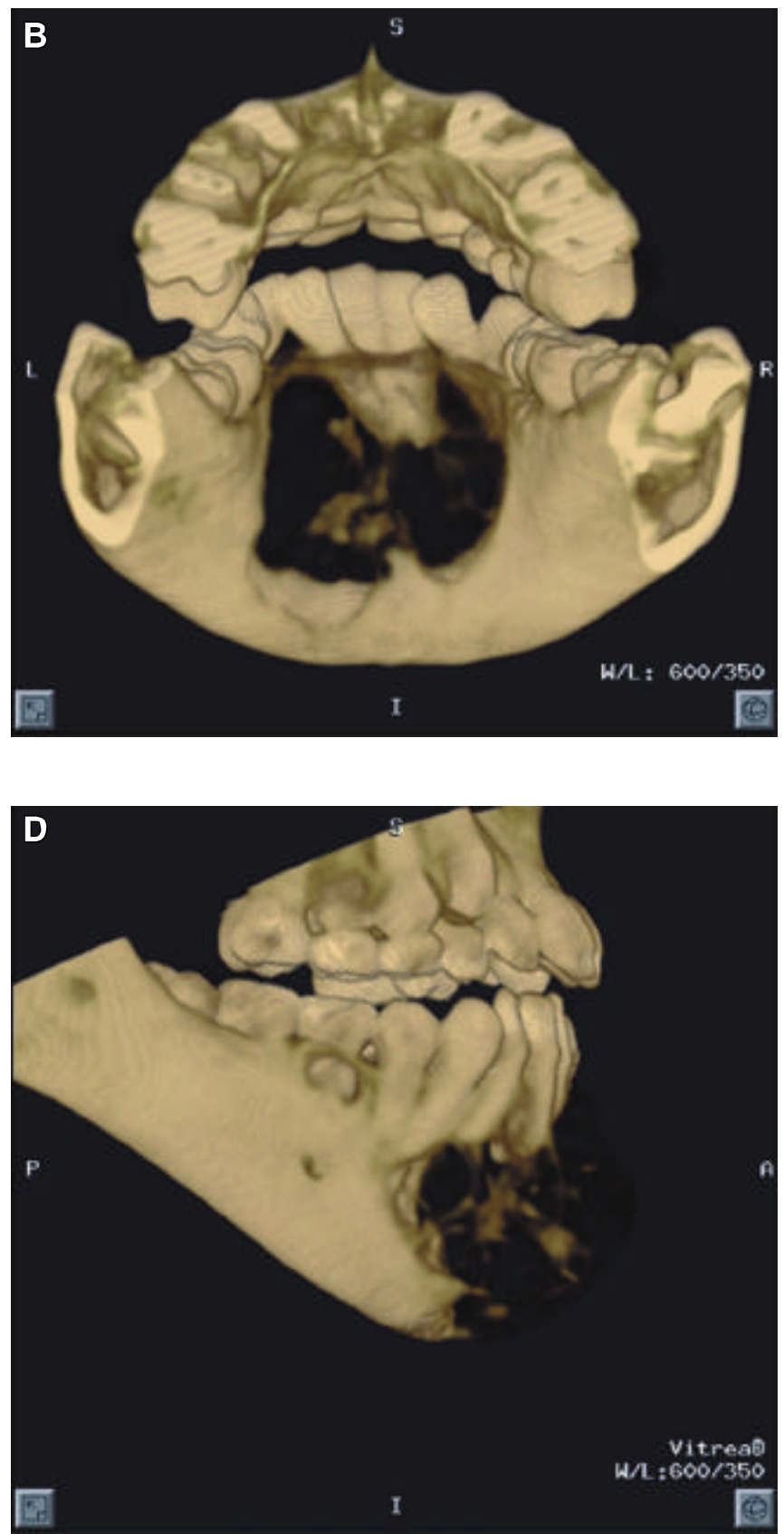

FIGURE 2 - The 3D-CT bone protocol shows the destruction of bone caused by the lesion and the aspect of the mandible from the anterior (A), posterior (B), left (C) and right (D) views. 
CAVALCANTI, M. de G. P.; RUPRECHT, A.; VANNIER, M. W. 3D-CT vascular setting protocol using computer graphics for the evaluation of maxillofacial lesions. Pesqui Odontol Bras, v. 15, n. 3, p. 229-236, jul./set. 2001.
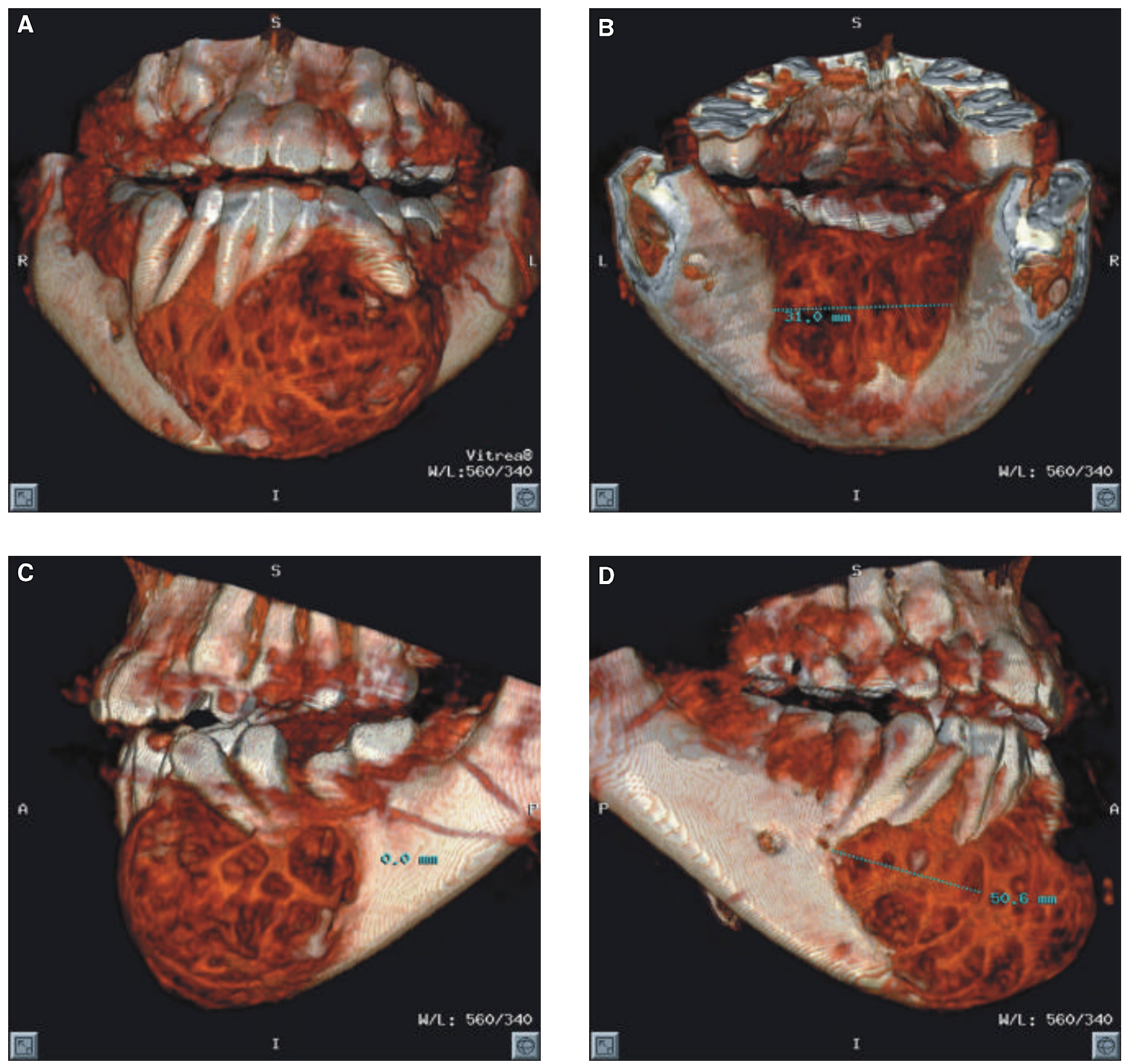

FIGURE 3 - The 3D-CT vascular protocol depicts in red the soft tissue of the lesion in relationship with the mandible, demonstrating all its components, extension and dimensions in anterior (A), posterior (B), left (C) and right (D) views.

using different protocols, and the correlation with the histopathological findings.

In $70 \%$ of the cases, it was possible to define the findings through MPR images. In $82 \%$ it was possible to define the findings through $3 \mathrm{D}-\mathrm{CT}$ images using the bone protocol. In $85 \%$, a very satisfactory assessment was possible by means of the 3D-CT vascular protocol. Furthermore, in more than $90 \%$ of the cases, the combination of both
3D-CT protocols was fundamental for the diagnosis. We studied cases of central giant cell granuloma, ossifying fibroma and fibrous dysplasia. All the cases of fibrous dysplasia presented with poor vascularity. The cases of central giant cell granuloma and those of ossifying fibroma presented with rich vascularity, which was more pronounced in the former. In relation to the 3D-CT bone protocol, the results added valuable informa- 
CAVALCANTI, M. de G. P.; RUPRECHT, A.; VANNIER, M. W. 3D-CT vascular setting protocol using computer graphics for the evaluation of maxillofacial lesions. Pesqui Odontol Bras, v. 15, n. 3, p. 229-236, jul./set. 2001.

tion since the two radiologists noticed the increased volume of bone, without destruction, in fibrous dysplasias; they also agreed in defining the trabecular area of ossifying fibromas, and the large destruction of mandibular bone in the case of central giant cell granuloma.

The MPR images showed a high multilocular radiolucency with numerous internal septa. Considerable expansion of bone was evident in both buccal and lingual aspects (Figure 1). The 3D-CT bone protocol depicted a large destruction of bone with dislocation of the anterior teeth, also demonstrating the degree of bucco-lingual and inferior expansion of the lesion in the body of the mandible, as well as the internal trabeculae (Figure 2). The 3D-CT vascular protocol demonstrated the dimensions of vascularity (width from the posterior view $=31.0 \mathrm{~mm}$, and width from the lateral view $=50.6 \mathrm{~mm}$ ) and, subsequently, the dimensions of the soft tissue lesion (Figure 3).

The 3D-CT vascular protocol showed a very good level of agreement with the histopathological examination, which was used as a gold standard. MPR showed some degree of disagreement and, for the $3 \mathrm{D}-\mathrm{CT}$ bone protocol, there was disagreement in only 2 cases.

\section{DISCUSSION}

3D-CT reconstructed images of head and neck tumors are an important aid to clinicians in preand postoperative assessment of lesions ${ }^{12,9,10,11,14}$. We carried out our study based on the usefulness of 3D computer graphics in the delineation of lesions using the vascular setting protocol.

With the advent of subsecond spiral CT, the range that can be covered in a given period of time (e.g., during the critical phase of vascular enhancement) has increased from $25 \%$ to $30 \%{ }^{15}$. Nowadays, the multislice volumetric CT scanners greatly improved both image quality and productivity $^{15}$. In our study, we used the newest generation of spiral CT, which permits $0.5 \mathrm{sec}$ for the thickness of each slice, with a high quality of MPR and $3 \mathrm{D}$ reconstructed images.

One of the advantages of spiral CT is the ability to reconstruct overlapping slices at every table position within the scan volume. Thus, the quality of $3 \mathrm{D}$ reconstructed images and coronal and sagittal MPR images is considerably improved ${ }^{17,21}$. Another advantage of spiral CT is related to the use of contrast medium. For the current study, contrast medium was necessary, in order to permit the deline- ation of the neoplasm using the vascular setting. In their study, SPREER et al. ${ }^{21}$ (1995) found that with spiral CT they needed one third less contrast medium than with conventional $\mathrm{CT}$ in order to obtain sufficient tissue contrast and soft tissue enhancement. The homogeneity of contrast enhancement was significantly higher when using the spiral technique.

BERTAND et al. ${ }^{3}$ (1993) stated that giant cell granulomas and ossifying fibromas, but not fibrous dysplasias, present at an earlier age are more clinically aggressive and more vascularized. We felt that, based on this description of increased vascularity, the vascular setting protocol that we have previously described would be useful for delineating the giant cell granuloma. This protocol is based upon the increased accumulation of contrast medium in and around the lesion, due to tumor-related increased vasculature, resulting in increased contrast. The vascular setting protocol selectively colorizes the areas of enhanced contrast accumulation and, thus, defines the limits of the lesion.

EL-LABBAN $^{13}$ (1997) performed a study with the purpose of investigating the vascular findings of the central giant cell granuloma and discussing the pathogenesis of this lesion. The author concluded that the stroma of the central giant cell granuloma has a strong vascularity with hemorrhagic areas and dilated blood vessels. Central giant cell granulomas consist of a rich conjunctive matrix with a rich capillar vascularity ${ }^{23}$; histologically, those lesions have highly vascular growths ${ }^{2}$. The differential diagnosis of radiolucent lesions can include vascular lesions. Most of these lesions are conditions such as central giant cell granulomas, hemangiomas, traumatic bone cysts and fibro-osseous lesions ${ }^{6}$. Due to the thin-walled vascular spaces, hemorrhage can be very well seen. Intravascular invasion by giant cells can also be seen ${ }^{25}$. Hemorrhage and dilated vascular channels are often closely associated with central giant cell granulomas $^{1,19}$. The most interesting finding was the staining pattern of blood vessels in the central giant cell granuloma ${ }^{18}$.

The usefulness of 3D-CT for the visualization of the involvement of bone and soft tissue masses in neoplasms has increased due to improvements of image processing. Spiral CT based 3D imaging with contrast has been further improved through the use of the vascular setting protocol, which permits soft tissue differentiation based upon blood and contrast perfusion. This method was used 
CAVALCANTI, M. de G. P.; RUPRECHT, A.; VANNIER, M. W. 3D-CT vascular setting protocol using computer graphics for the evaluation of maxillofacial lesions. Pesqui Odontol Bras, v. 15, n. 3, p. 229-236, jul./set. 2001.

here to localize and measure a giant cell central granuloma using a unique computer graphics protocol that had been previously validated using cadaver heads ${ }^{9}$. In the current paper we show a clinical application of that experiment, demonstrating the possibility of its clinical use.

Radiographically, the central giant cell granuloma appears, with equal frequency, as a unilocular radiolucence or as multilocular radiolucences. The border of the lesion may be well or poorly defined, and the tumor frequently extends beyond the radiographic margins. The clinical behavior of these lesions is quite variable and difficult to predict $^{4,24,27}$. There has been considerable interest in predicting the aggressiveness of these lesions; the perforation of the cortical bone, when present, indicates more aggressive lesions $\mathbf{s}^{4,24,27}$.

In our study, MPR images revealed destruction, cortical thinning, large lesions and septa. However, 3D-CT images were necessary to confirm the extent of the lesion and of the destruction. The cortical destruction was not very well seen in MPR images but satisfactorily seen in our 3D images. The 3D vascular image showed the invasion of the lesion within the interior aspects of the mandible and its proximity to adjacent structures, determining the real topography of the lesion. These 3D protocol views clearly showed both the osteoblastic and osteolytic aspects of the tumor.

As stated above, the ability of CT to produce contrast enhancement of a lesion is related to selective accumulation of contrast medium within the neoplasm. The lesions tend to stimulate angiogenesis, so that the number of blood vessels associated with the tumor increases, and there is also an increase in extravascular leakage ${ }^{22}$. That adds to the accumulation of contrast medium around the lesion. Collectively, it leads to increased radiopacity of the periphery of the neoplasm, often called "blush", which is commonly found on CT examinations ${ }^{20,22}$. Consequently, the attenuation coefficient or CT number of the periphery of the neoplasm is different from that of the neighbor tissue. Many authors have reported that this contrast enhancement can be used with 3D images to produce good visualization of lesions ${ }^{16}$. In our 3D images, color assignment is based on the attenuation coefficient of tissues as measured in Hounsfield units. Contrast medium accumulation within the tumor due to the vascular changes described above allows for selective colorization of the neo- plasm in relation to adjacent tissues, using the vascular setting.

In a paper that validated linear measurements using the $3 \mathrm{D}$ vascular setting protocol, CAVALCANTI et al. $^{8}$ (2000) found no statistically significant differences between physical and imaging measurements using the $3 \mathrm{D}$ vascular setting protocol. Using the same methodology, we demonstrated, in this paper, a clinical application in a patient with a giant cell central granuloma in the mandible. We localized the lesion using the vascular protocol, and performed measurements for treatment planning and evaluation. Also using the 3D bone protocol we demonstrated some bony aspects of the lesion that were not well defined on $2 \mathrm{D}-\mathrm{CT}$ images.

The available computer software allows for the use of image enhancement algorithms, 3D rendering of great amount of data, viewing and slicing of volumes in any direction and plane, and identification of different surfaces and tissues through co$\operatorname{lors}^{8,26}$. The process of acquisition of data is improved using properties of the software such as color transparence in the contrast area ${ }^{8}$. We think that this methodology can distinguish some lesions based on their vascularity. We think that, with our methods, 3D-CT may play an important role in establishing treatment protocols since it allows for the determination of the size, position and extension of tumor masses. Further researches must be developed in order to better clarify our hypothesis.

\section{CONCLUSIONS}

We have shown that the 3D-CT vascular setting protocol is a useful imaging modality for the diagnosis and treatment planning of neoplastic lesions. For that, we demonstrated its clinical application in a case of aggressive giant cell granuloma. The computer software that permits the utilization of preset protocols makes it possible to automatically link volume rendering to the scanning process, which originates appropriate 3D reconstructed images with high image quality. We have demonstrated the usefulness of imaging processing with qualitative and quantitative analyses to improve the diagnosis and, thus, the treatment plan.

\section{ACKNOWLEDGMENTS}

Grants from the State of São Paulo Research Foundation (FAPESP, 99/10276-4), Brazil. Project I of Research - Vice-rectorate, University of São Paulo. 
CAVALCANTI, M. de G. P.; RUPRECHT, A.; VANNIER, M. W. 3D-CT vascular setting protocol using computer graphics for the evaluation of maxillofacial lesions. Pesqui Odontol Bras, v. 15, n. 3, p. 229-236, jul./set. 2001.

CAVALCANTI, M. de G. P.; RUPRECHT, A.; VANNIER, M. W. Protocolo vascular por meio da 3D-TC utilizando a computação gráfica para avaliação de lesões maxilo-faciais. Pesqui Odontol Bras, v. 15, n. 3, p. 229-236, jul./set. 2001.

Neste trabalho, demonstramos os aspectos de um granuloma central de células gigantes por meio da tomografia computadorizada (TC) em espiral baseada na reconstrução de imagem em três dimensões (3D), utilizando a computação gráfica, e a importância do protocolo vascular permitindo um melhor diagnóstico, visualização e obtendo dimensões da lesão. Foram analisados 21 pacientes com lesões maxilo-faciais de origens neoplásicas e proliferativas. Dois radiologistas analisaram as imagens. A utilidade da interação da reconstrução da imagem por meio da computação gráfica, especialmente utilizando o protocolo vascular para análises qualitativas e quantitativas para o diagnóstico, planejamento de tratamento e evolução, assim como para a localização da extensão da lesão foi demonstrada. Isto é um importante adjunto para a evolução destas lesões em relação a cortes axiais em TC e para imagens por meio de 3D-TC para estruturas ósseas.

UNITERMOS: Tomografia computadorizada por raios X; Processamento de imagem assistido por computador; Granuloma de células gigantes; Mandíbula.

\section{BIBLIOGRAPHIC REFERENCES}

1. ANDERSEN, L.; FEJERSKOV, O.; PHILIPSEN, H. P. Oral giant cell granuloma. A clinical and histological study of 129 new cases. Acta Pathol Microbiol Scand, v. 81, p. 606-616, 1973.

2. ANDERSEN, L.; FEJERSKOV, O.; THEILADE, J. Oral giant cell granuloma. An ultrastructural study of vessels. Acta Pathol Microbiol Scand, v. 83, p. 69-76, 1975.

3. BERTRAND, B.; ELOY, P.; CORNELIS, J. P. et al. Juvenile aggressive cemento-ossifying fibroma: case report and review of the literature. Laryngoscope, v. 103, p. 1385-1390, 1993.

4. BORDNER, L.; BAR-ZIV, J. B. Radiographic features of central giant cell granuloma of the jaws in children. Pediatr Radiol, v. 26, p. 148-151, 1996.

5. BODNER, L.; BAR-ZIV, J.; KAFFE, I. CT of cystic jaw lesions. J Comput Assist Tomogr, v. 18, p. 22-26, 1994.

6. BURKES, E. F. Vascular leiomyoma of the mandible: report of a case. J Oral Maxillofac Surg, v. 53, p. 65-66, 1995.

7. CAVALCANTI, M. G. P.; RUPRECHT, A.; BONOMIE, J. M.; VANNIER, M. W. Accuracy and precision of spiral CT in the assessment of neoplastic lesions associated with the mandible. Acad Radiol, v. 7, p. 94-99, 2000.

8. CAVALCANTI, M. G. P.; RUPRECHT, A.; BONOMIE, J. M.; VANNIER, M. W. The validation of 3D spiral CT-based measurements of simulated maxillofacial neoplasms. Oral Surg Oral Med Oral Pathol Oral Radiol Endod, v. 89. p. 753-758, 2000.

9. CAVALCANTI, M. G. P.; RUPRECHT, A.; QUETS, J. Evaluation of maxillofacial fibrosarcoma using computer graphics and spiral computed tomography. Dentomaxillofac Radiol, v. 28, p. 145-151, 1999.

10. CAVAlCANTI, M. G. P.; RUPRECHT, A.; QUETS, J. Progression of squamous cell carcinoma evaluated using computer graphics of spiral computed tomography. Dentomaxillofac Radiol, v. 28, p. 238-244, 1999.

11. CAVALCANTI, M. G. P.; RUPRECHT, A.; VANNIER, M. W. Imaging of cysts and tumors using computer graphics form 2D-CT and 3D-CT reconstructed images. Radiology, v. 207, p. 176-177, 2000.
12. CAVALCANTI, M. G. P.; VANNIER, M. W. Measurement of the volume of oral tumours by three-dimensional spiral computed tomography. Dentomaxillofac Radiol, v. 29, p. 35-40, 2000.

13. EL-LABBAN, N. G. Intravascular fibrin thrombi and endothelial cell damage in central giant cell granuloma. $\mathbf{J}$ Oral Pathol Med, v. 26, p. 1-5, 1997.

14. FAGELMAN, D.; HUANG, A. B. Prospective evaluation of lesions of the mandible and maxilla: findings on multiplanar and three-dimensional CT. Am J Roentgenol, v. 163, p. 693-698, 1994.

15. FOX, S. H.; TANENBAUM, L. N.; ACKELSBERG, S. Future directions in CT technology. Neuroimaging Clin N Am, v. 8, p. 497-513, 1998.

16. GHOLKAR, A.; ISHERWOOD, I. Three-dimensional tomographic reformations of intracranial vascular lesions. Br J Radiol, v. 61, p. 258-262, 1988.

17. KALENDER, W. A.; POLACIN, A.; SUSS, C. A comparison of conventional and spiral CT: an experimental study on the detection of spherical lesions. J Comput Assist Tomogr, v. 18, p. 167-176, 1994.

18. LIM, L.; GIBBINS, J. R. Immuhistochemical and ultrastructural evidence of a modified microvasculature in the giant cell granuloma of the jaws. Oral Surg Oral Med Oral Pathol Oral Radiol Endod, v. 79, p. 190-198, 1995.

19. ODELL, E. W. Hybrid central giant cell granuloma and central odontogenic fibroma-like lesions of the jaws. Histopathology, v. 30, p.165-171, 1997.

20. SOM, P. M.; LANZIERI, S. F.; SACHER, M. et al. Extracranial tumor vascularity: determination by dynamic CT scanning. Part I: concepts and signature curves. Radiology, v. 154, p. 401-405, 1985.

21. SPREER, J.; KRAHE, T.; JUNG, G.; LACKNER, K. Spiral versus conventional $\mathrm{CT}$ in routine examinations of the neck. J Comput Assist Tomogr, v. 19, p. 905-910, 1995.

22. TAKEDA, N.; TANAKA, R.; NAKAI, O.; UEKI, K. Dynamics of contrast enhancement in delayed computed tomography of brain tumors: tissue-blood ratio and differential diagnosis. Radiology, v. 142, p. 663-668, 1982. 
CAVALCANTI, M. de G. P.; RUPRECHT, A.; VANNIER, M. W. 3D-CT vascular setting protocol using computer graphics for the evaluation of maxillofacial lesions. Pesqui Odontol Bras, v. 15, n. 3, p. 229-236, jul./set. 2001.

23. TIMOSCA, G.; GAVRILITA, L. Le granulome périphérique à cellules géantes des maxillaires. Étude sur 173 cas. Revue de Stomatologie, v. 77, p. 587-597, 1976.

24. WALSTAD, R. W.; FIELDS, T.; SCHOW, S. R.; McKENNA, S. J. Expansile lesion of the anterior maxilla. J Oral Maxillofac Surg, v. 57, p. 595-599, 1999.

25. WENIG, B. M.; MAFEE, M. F.; GHOSH, L. Fibro-ossoeus, osseous, and cartilaginous lesions of the orbit and para- orbital region. Radiol Clin N Am, v. 36, p. 1241-1259, 1998.

26. WIEGAND, D. A.; PAGE, R. B.; CHANNIN, D. S. The surgical workstation: surgical planning using generic software. Otolaryngol Head Neck Surg, v. 109, p. 434-440, 1993.

27. WHITAKER, S. B.; WALDRON, C. A. central giant cell lesion of the jaws. Oral Surg Oral Med Oral Pathol Oral Radiol Endod, v. 75, p. 199-208, 1993.

Recebido para publicação em 08/03/01 Enviado para reformulação em 04/05/01 Aceito para publicação em 01/06/01 